Proc. Estonian Acad. Sci. Eng., 2001, 7, 2, 174-192

\title{
SAAREMAA DEEP HARBOUR LAYOUT DESIGN AND COMPUTER SIMULATION OF THE WAVE CLIMATE AND SEDIMENT TRANSPORT
}

\author{
Toomas LIIV ${ }^{\mathrm{a}}$ and Uno LIIV \\ a Institute of Mechanics, Tallinn Technical University, Ehitajate tee 5, 19086 Tallinn, Estonia; \\ toomas@corson.ee \\ b Corson Consulting, Akadeemia tee 21, 12618 Tallinn, Estonia; uno@corson.ee
}

Received 20 March 2001, in revised form 29 March 2001

\begin{abstract}
The layouts for the three proposed sites for the Saaremaa Island deep harbour were designed at Corson Consulting. The layouts were designed on the basis of geological, hydrometeorological, and wave and current conditions. Emphasis was given to the impact of the future harbour on nature. The layouts were used as the basis for wave and velocity field calculations using program MIKE 21. Wave and velocity characteristics were determined for wind directions that are significant for the harbour sites. SandCalc 2.0 was applied for calculation of wave generated shear stresses on the bottom of the seabed around the harbour sites taking into account the local bed characteristics. The calculated shear stresses were used for the analysis of the sediment processes. The results indicate that Suuriku-Kuriku site is the most favourable site for the harbour. The proposed layout protects satisfactorily the harbour basin from most wind directions. The movement of the alluvial material into the harbour basin does not generate problems due to the characteristics of the seabed. Calculation shows that at Suuriku-Kuriku less dredging work is needed than at the other sites.
\end{abstract}

Key words: harbours, wave climate, sediment transport, MIKE 21.

\section{INITIAL CONDITIONS AND DATA FOR THE DEEP HARBOUR LAYOUT DESIGN}

Investigations of the location of the Saaremaa deep harbour and its layout design were carried out for the sites proposed by the Estonian Ministry of Environment and based on the business plan presented by Saaremaa County. According to these, three possible harbour sites (Undva, Suuriku-Kuriku, and Vaigu) were established. These sites are situated around Tagamõisa Peninsula on the NW part of the Estonian biggest island Saaremaa. According to the regional 
development plan of the Saaremaa County, deep harbour must meet the following requirements.

Dimensions of three separate basins must be:

1) $300 \times 150 \mathrm{~m}$, depth $10.0 \mathrm{~m}$ - for big cruise vessels,

2) $300 \times 150 \mathrm{~m}$, depth $7.0 \mathrm{~m}-$ for medium vessels,

3) $200 \times 150 \mathrm{~m}$, depth $3.7 \mathrm{~m}$ - for yachts.

The dimensions of the greatest vessel to be berthed are: length 210 , width 30 , and draught $8.5 \mathrm{~m}$. Users of the deep harbour will be regular passenger ships departing from Helsinki and Stockholm, ro-ro type cargo vessels, different types of yachting, border guard, and rescue vessels. The number of passengers visiting the harbour is expected to be yearly 200000 , with daily maximum of 1500 . A yearly pass of 30000 cars and seasonally weekly 500 trailers and buses are expected.

Different normative materials $\left[{ }^{1-5}\right]$ concerning harbour design, constructions, navigation, etc., were used in the design of the layouts. The investigation was supposed to include also numerical simulation of the wave field of the Baltic Sea open area, investigation of seawater currents and circulations, geological survey of the sea bottom, and simulation of the possible spread of the pollution under different wind conditions in areas close to the proposed sites of the deep harbour. The results of these investigations are presented in this issue $\left[{ }^{6-9}\right]$ and have been taken into account in the designs for the layouts of the harbours.

By designing the layouts of the deep harbour at different sites the following additional conditions were considered.

1. All proposed deep harbour sites are more or less open to the wave trains generated by the winds from the Baltic Sea and therefore around the proposed areas waves of the height 4.5-5.0 m are to be expected with a probability of $30 \%$. To maintain the safety of navigation and berthing of the moored ships, the main breakwater must be designed to keep out the wave trains running to the site from main directions of the blowing winds. The breakwater height must exceed half the amplitude of the wave plus $1 \mathrm{~m}$. It means that breakwaters, quay surface and the harbour infrastructure must be $3.5 \mathrm{~m}$ over the Baltic Sea "0" level. If a part of a breakwater is to be used for solving the logistical problems, a parapet with a minimum height of 0.9 m must be built on the side of the open sea. Therefore designed breakwater must break up and disperse heavy waves, isolating berthing basins from the sea influence; inner side of the breakwater is to be used as the berthing quay and berthing area is to be divided into three separate basins.

2. Due to large volumes of necessary dredging works and longspun breakwaters it is meaningful to use the dredged limestone material in the mound of the rubble stone construction of the main breakwater. Outside slope of the breakwater is from $1: 1.5$ to $1: 2$ and the core from limestone shivers must be covered with two layers of granite rocks: inner layer with mass of the individual rocks of $40-65 \mathrm{~kg}$, and outer layer with the rocks of more than $250 \mathrm{~kg}$. Granite rocks may be replaced by concrete elements having the same mass, for example, by tetrapodes. Interior wall of the breakwater, when it is used for berthing, must be a 
vertical wall made from concrete blocks with $50 \mathrm{t}$ mass each. Width of the breakwater top must satisfy the conditions for two-way traffic and demands for the turning radius of the trailers unloaded from vessels through the ramp. Vertical wall berthing quays are also designed from the concrete blocks. Breakwaters and quays are to be founded on the limestone base and it requires the removal of all sediment material, including sand, from beneath of the structures.

Bathymetry data for the wave hindcast studies was obtained and digitized using the maps issued by the former USSR Ministry of Defence (scale 1:25 000) describing seabed around the Tagamõisa Peninsula. For test calculations the map "Baltic Sea from island Vilsandi to peninsula Kõpu" issued on 1998 by the Estonian Maritime Board (scale 1:100 000) was used. Bathymetric situation around the area of the possible deep harbour sites was specified using maps in scale 1:500 provided by "OÜ Geodeesiabüroo".

Open sea initial wave conditions, obtained with the WAM IV [ $\left.{ }^{8}\right]$ wave model, were used. The grid cell used in computations was equal to $1 \times 1 \mathrm{mi}$. The starting point for the calculations with the model MIKE $21 \mathrm{NSW}\left[{ }^{10,11}\right]$ was located at $58^{\circ} 30^{\prime} \mathrm{N}, 21^{\circ} 40^{\prime} \mathrm{E}$. Wave parameters for calculation were: mean wave height $8.5 \mathrm{~m}$, mean wave period $10.7 \mathrm{~s}$, wave length in the peak period $12.3 \mathrm{~m}$ in the Uudepanga Bay at $30 \mathrm{~m}$ depth. This data corresponds to $25 \mathrm{~m} / \mathrm{s}$ wind blowing from west during $24 \mathrm{~h}$.

\section{WAVE MODELLING AT THE COASTLINE AND IN THE HARBOUR SITES}

\subsection{Wave hindcast}

To simulate the evolution of random, short-crested, wind-generated waves in coastal waters, a numerical simulation program MIKE $21\left[^{[0,11}\right]$ was used. This program is capable of computing wave propagation, wave generation by wind, non-linear wave-wave interactions and dissipation for given bottom topography, wind field, water level, and current field in waters of deep, intermediate, and finite depth. MIKE 21 consists of modules from which in the present study two modules were used for the wave hindcast and velocity field calculations: NSW Nearshore Spectral Wind-Wave Module and BW - Boussinesq Wave Module. Additionally, when presenting the results of the calculations, Pre- and Postprocessing module was included.

\subsection{Nearshore Spectral Wind-Wave Module NSW}

MIKE $21 \mathrm{NSW}\left[{ }^{10}\right]$ is a wind-wave model which describes the propagation, growth, and decay of short-period and short-crested waves in nearshore areas. The model takes into account the effects of refraction and shoaling due to varying depth, local wind generation, and energy dissipation due to bottom 


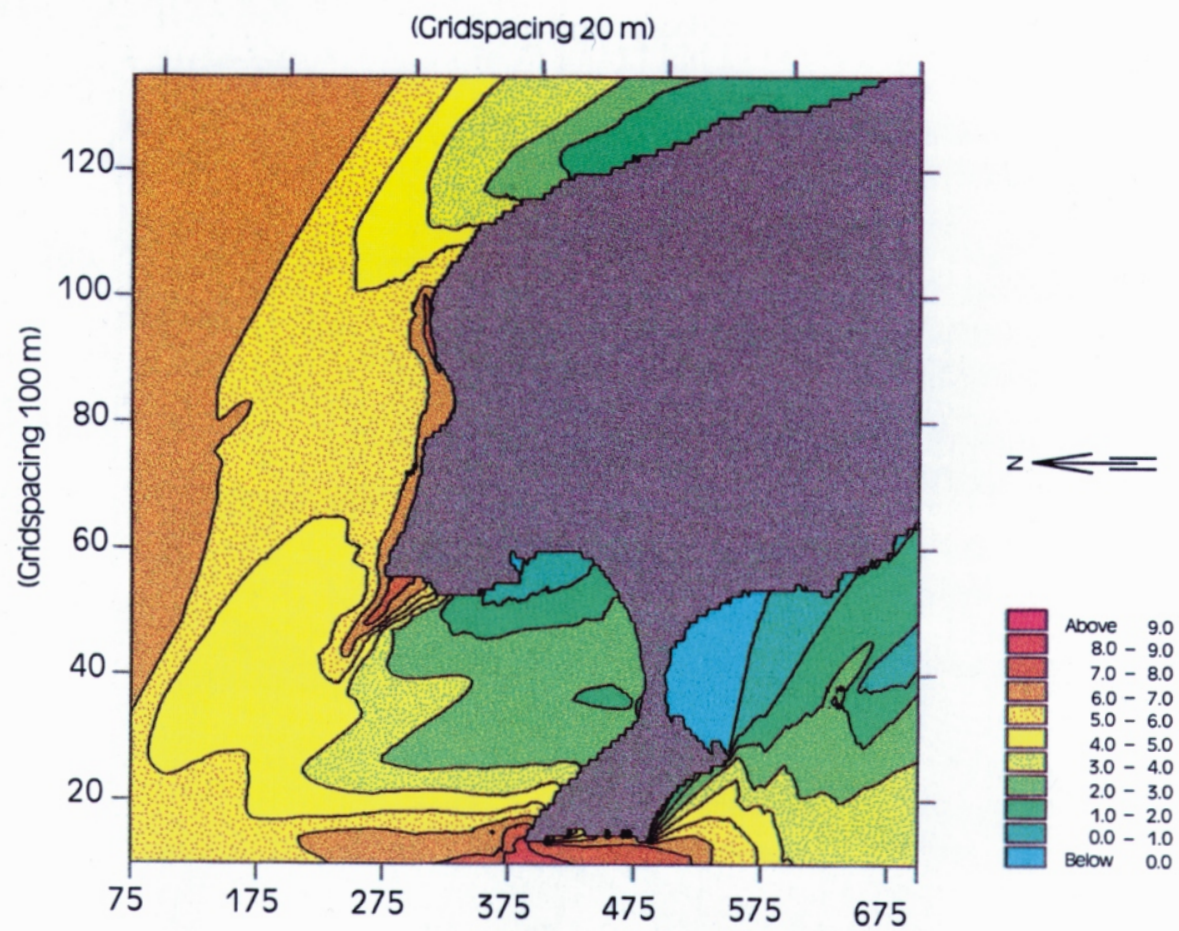

Fig. 1. Significant wave heights around Tagamõisa Peninsula, winds blowing from north.

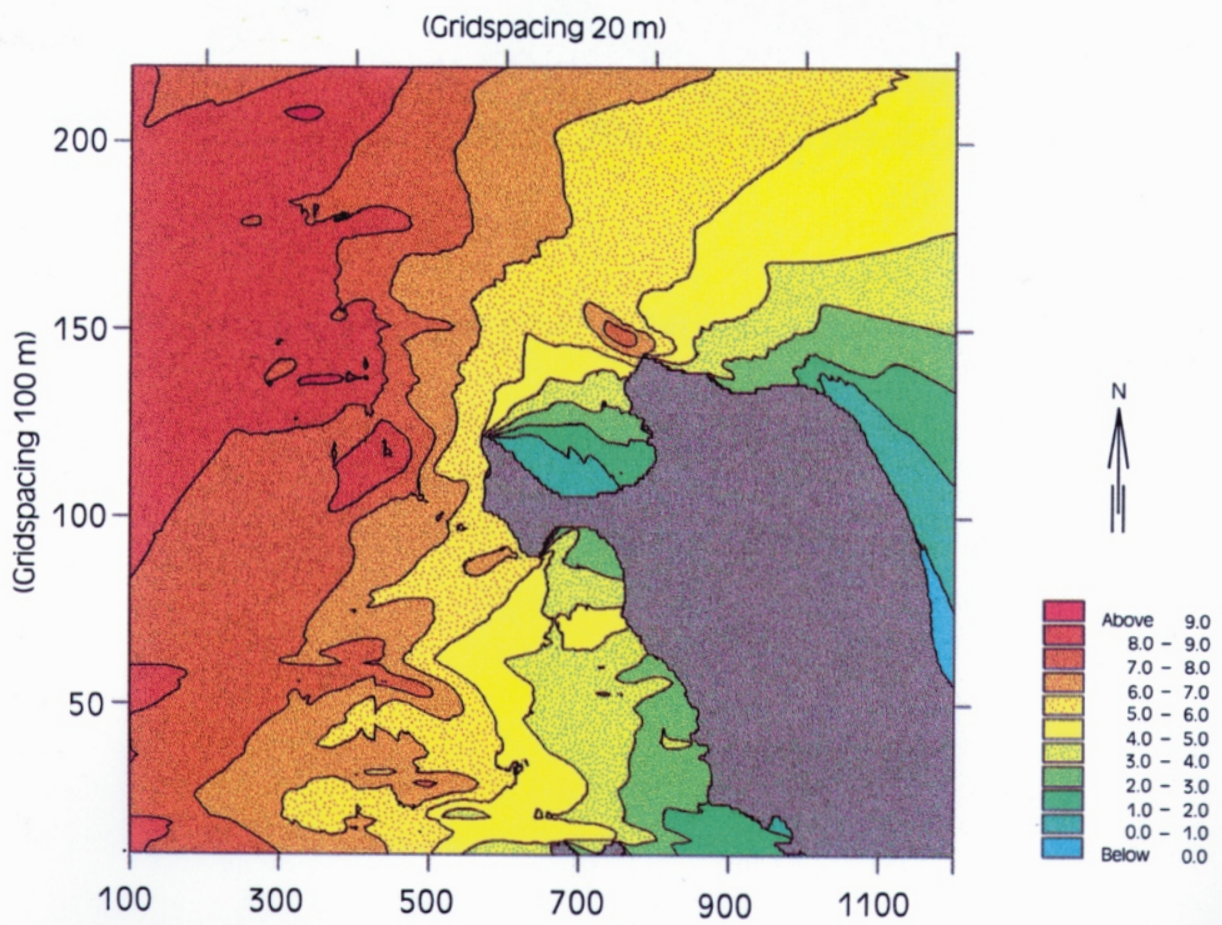

Fig. 2. Significant wave heights around Tagamõisa Peninsula, winds blowing from west. 


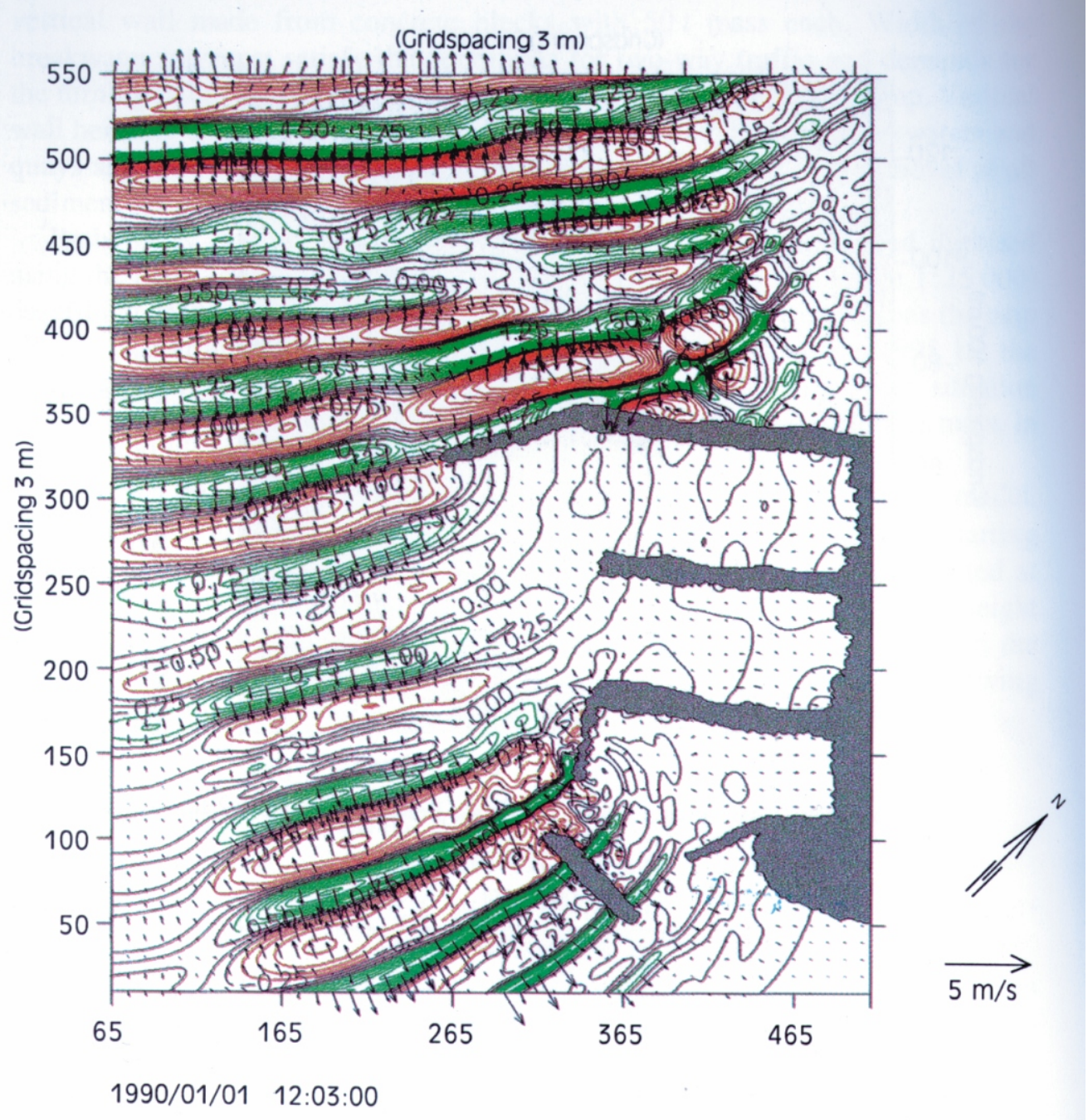

Fig. 6. Wave amplitudes and velocity vector field at Undva harbour for north wind wave trains, scale 1:6500. 


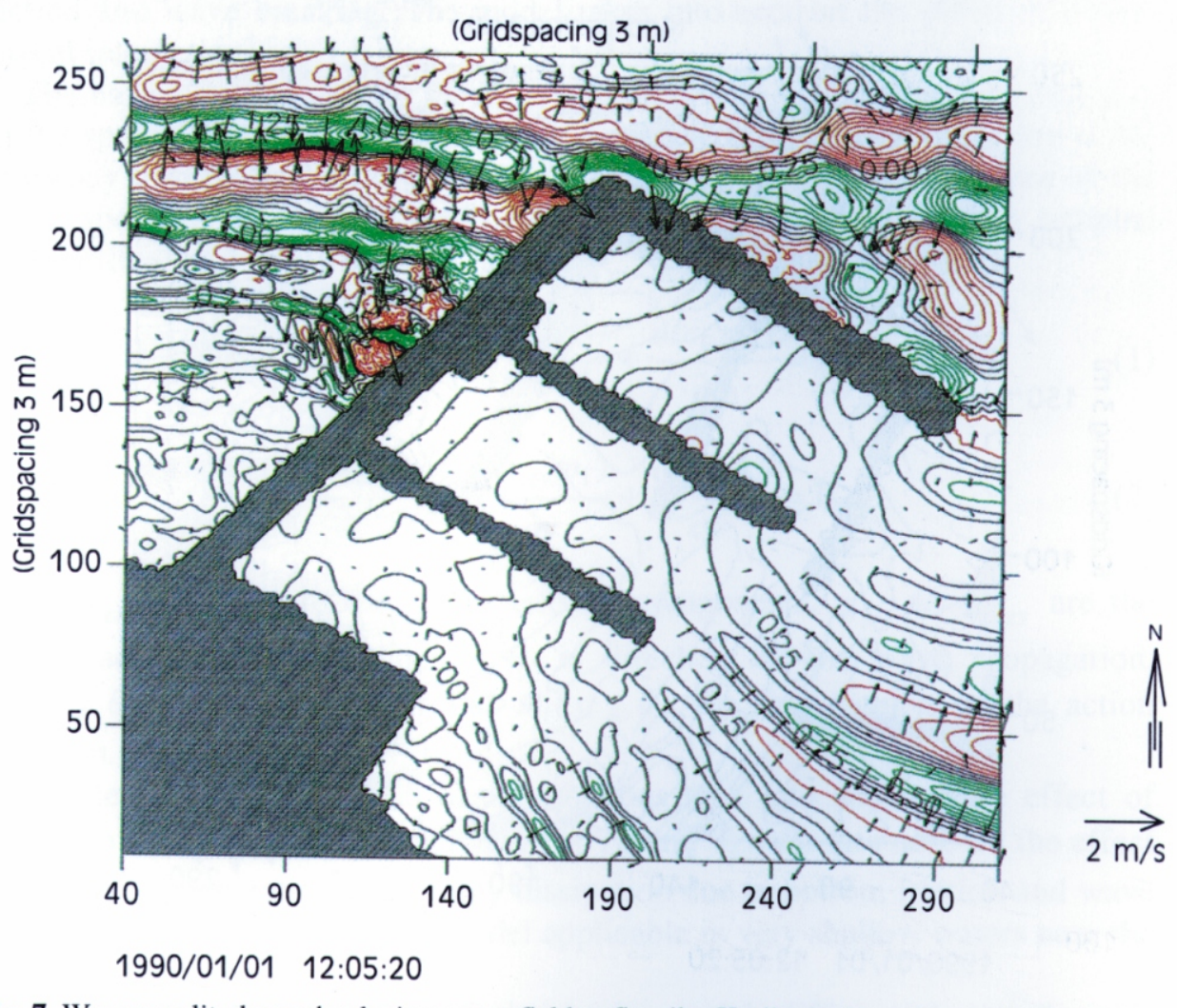

Fig. 7. Wave amplitudes and velocity vector field at Suuriku-Kuriku harbour for north wind wave trains, scale 1:6000. 


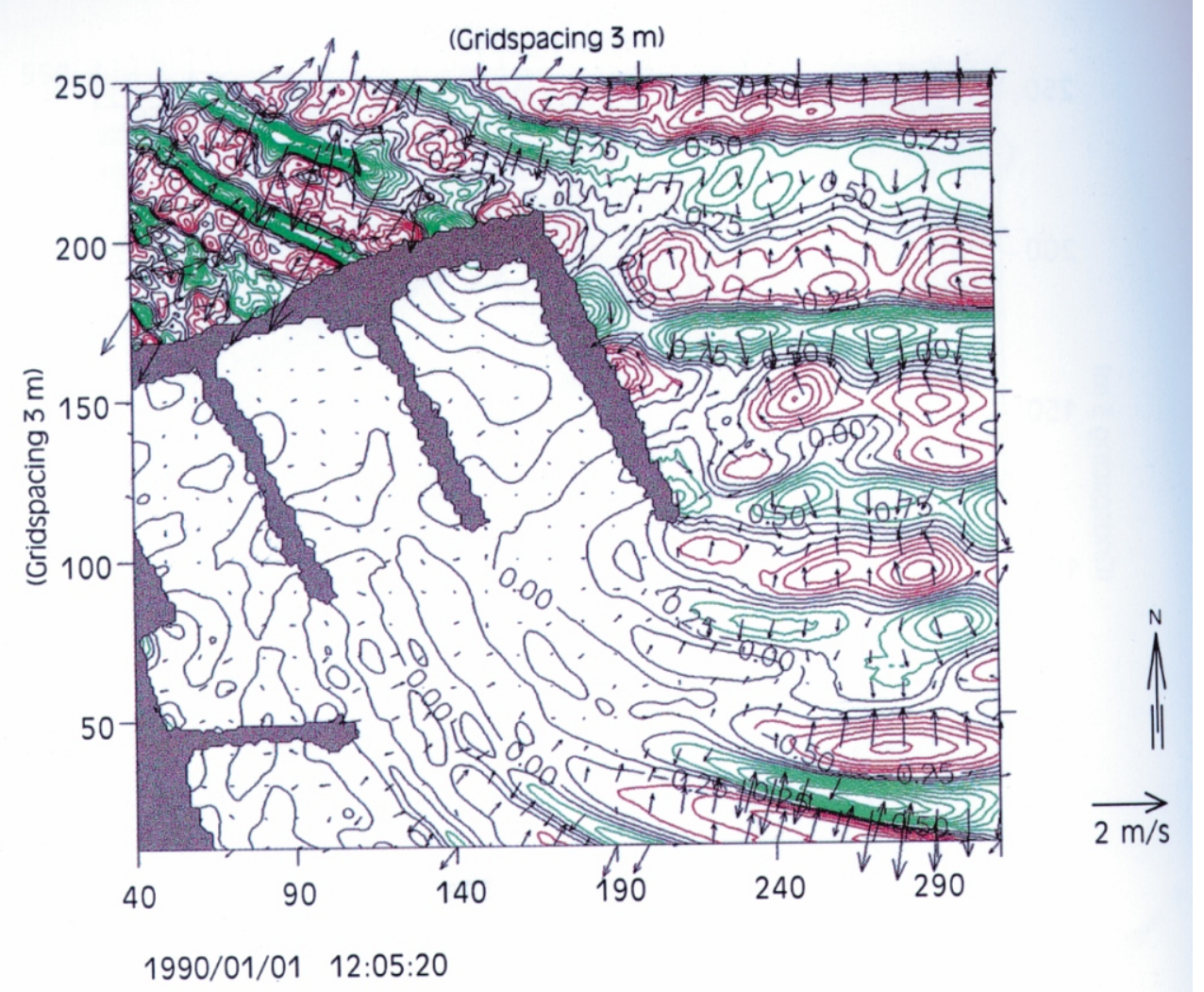

Fig. 8. Wave amplitudes and velocity vector field at Vaigu harbour for NW wind wave trains, scale 1:4500. 
friction and wave breaking. The model takes into account the effect of wavecurrent interaction.

The basic equations of the model are derived from the conservation equation for the spectral wave action density. The parameterization of this equation in the frequency domain is performed introducing the zeroth and first moment of the action spectrum as dependent variables. This leads to the following coupled partial differential equations

$$
\begin{gathered}
\frac{\partial\left(c_{g x} m_{0}\right)}{\partial x}+\frac{\partial\left(g_{g y} m_{0}\right)}{\partial y}+\frac{\partial\left(c_{\theta} m_{0}\right)}{\partial \theta}=T_{0}, \\
\frac{\partial\left(g_{g x} m_{1}\right)}{\partial x}+\frac{\partial\left(c_{g y} m_{1}\right)}{\partial y}+\frac{\partial\left(c_{\theta} m_{1}\right)}{\partial \theta}=T_{1},
\end{gathered}
$$

where $c_{g x}$ and $c_{g y}$ are the group velocity components, $g_{g x}$ and $g_{g y}$ are the gravity acceleration components, $\theta$ is direction of the wave propagation, $m_{0}(x, y, \theta)$ is zeroth moment and $m_{1}(x, y, \theta)$ the first moment of the action spectrum.

The left-hand sides of the basic equations take into account the effect of refraction and shoaling. The source terms $T_{0}$ and $T_{1}$ take into account the effect of local wind generation and energy dissipation due to bottom friction and wave breaking. This effect makes the model applicable in very shallow waters near the coastline.

The spatial discretization of the basic partial differential equations is performed using the Eulerian finite difference technique. The zeroth and first moment of the action spectrum are calculated on the rectangular grid for a number of discrete directions (in the present case the model included waves propagating at $-60^{\circ}$ to $+60^{\circ}$ from the wind direction).

Outputs from the model are integral wave parameters: significant wave height, mean wave period, directional standard deviation, and radiation stresses. The radiation stresses allow the computation of the wave-induced currents, which are important in determining the sediment movement.

\subsection{Boussinesq Wave Module BW}

The MIKE $21 \mathrm{BW}$ module $\left[{ }^{11}\right]$ is based on the numerical solution of a new form of the two-dimensional Boussinesq equations. The latter include nonlinearity as well as frequency dispersion. The major restriction of the classical Boussinesq equations has been the limitation of the water depth. The new form of the Boussinesq equations incorporates the improvement of the dispersion characteristic, making MIKE $21 \mathrm{BW}$ suitable for simulation of the propagation of wave trains from deep to shallow water. 
The following equations of the conservation of mass and momentum integrated relative to the vertical co-ordinate, describe the flow and water level variations

$$
\frac{\partial \zeta}{\partial t}+\frac{\partial p}{\partial x}+\frac{\partial q}{\partial y}=0
$$

the momentum along $x$ axis

$$
\begin{aligned}
\frac{\partial p}{\partial t}+\frac{\partial}{\partial x}\left[\frac{p^{2}}{h}\right]+\frac{\partial}{\partial y}\left[\frac{p q}{h}\right]+ & g h \frac{\partial \zeta}{\partial x}+\frac{g}{C^{2}} \sqrt{\frac{p^{2}}{h^{2}}+\frac{q^{2}}{h^{2}}} \frac{p}{h}-E\left(\frac{\partial^{2} p}{\partial x^{2}}+\frac{\partial^{2} p}{\partial y^{2}}\right) \\
& =\frac{1}{3} D h\left(\frac{\partial^{3} p}{\partial x^{2} \partial t}+\frac{\partial^{3} q}{\partial x \partial y \partial t}\right),
\end{aligned}
$$

and momentum along $y$ axis

$$
\begin{aligned}
\frac{\partial q}{\partial t}+\frac{\partial}{\partial y}\left[\frac{q^{2}}{h}\right]+\frac{\partial}{\partial x}\left[\frac{p q}{h}\right]+ & g h \frac{\partial \zeta}{\partial y}+\frac{g}{C^{2}} \sqrt{\frac{p^{2}}{h^{2}}+\frac{q^{2}}{h^{2}}} \frac{p}{h}-E\left(\frac{\partial^{2} q}{\partial x^{2}}+\frac{\partial^{2} q}{\partial y^{2}}\right) \\
& =\frac{1}{3} D h\left(\frac{\partial^{3} q}{\partial^{2} y \partial t}+\frac{\partial^{3} p}{\partial x \partial y \partial t}\right) .
\end{aligned}
$$

The following symbols are used: $\zeta(x, y, t)$ - surface elevation (m), $p(x, y, t)-$ flux density in $x$ direction $\left(\mathrm{m}^{3} /(\mathrm{s} \mathrm{m})\right), q(x, y, t)-$ flux density in $y$ direction $\left(\mathrm{m}^{3} /(\mathrm{s} \mathrm{m})\right), h(x, y, t)$ - water depth $(\mathrm{m}), E$ - wave energy, $D$ - still water depth, $g$ - acceleration due to gravity $\left(\mathrm{m} / \mathrm{s}^{2}\right), C$ - Chezy resistance $\left(\mathrm{m}^{1 / 2} / \mathrm{s}\right), t-$ time $(\mathrm{s})$.

MIKE $21 \mathrm{BW}$ model is capable of reproducing the combined effects of shoaling, refraction, diffraction, and partial reflection of regular of irregular waves propagating over complex bathymetries. The model can be applied for studying wave dynamics in harbours.

\subsection{Calibration of the model}

In order to obtain truthful results with MIKE 21 during short period wave simulations, it is necessary that the model is used within specified limits and the grid and time scales have been determined with adequate resolution. To secure adequate results, the requested values are $T_{\min }-$ minimum period of the wave which can be used in simulations, $\Delta x$ - largest step of the grid, $\Delta t-$ time step, $t_{\min }-$ minimum duration of the simulation. 
To establish the minimum wave period it is necessary to determine if first deep water terms (DWT) should be included or not. For that a criterion of deep water wave steepness, $h / L_{0}$ ( $h$ - wave height, $L_{0}$ - deep water wave length), is used:

if $h / L_{0} \cong 0.60$, DWT has to be included,

if $h / L_{0} \cong 0.22$, DWT can be ignored.

From the point of view of practical calculations, inclusion of the DWT means diminishing the value of maximum time step and this results in longer simulation time. The calculations indicated that in the present case DWT is to be included.

Minimum wave period has been determined from the tables presented in MIKE $21 \mathrm{BW}$ Reference Manual $\left[{ }^{11}\right]$. From these tables the grid step and time scale have been derived. In the present simulations the following values of the parameters have been used:

$$
T_{\text {min }}=5.0 \mathrm{~s}, \Delta x=3.0 \mathrm{~m}, \Delta t=0.15 \mathrm{~s} .
$$

The time needed for the simulation consists of two parts: "warm up" of the model and simulation time. The "warm up" time is the time which is used by the model to establish the balance situation and is calculated as a time for the wave group with the shortest period to spread from the generation line to the furthermost point of the model and back to the generation line. According to $\left[{ }^{12}\right]$, in the present case the "warm up" time is 5 min.

\subsection{Wave hindcast and wave stress simulation in areas close to the harbour sites}

Using the NSW model and considering the bathymetry and wave trains generated from the selected wind directions for each harbour site, wave amplitude fields were calculated. Ten different cases were studied. On Figs. ${ }^{*}$ and $2^{*}$ two cases are presented showing significant wave heights (wave heights which occur with probability 0.3 ) around Tagamõisa Peninsula by northern and western winds. Calculated wave heights in areas close to the possible deep harbour sites were used in two different ways. First, for determining initial wave train conditions from every direction for the BW model which takes into account the proposed harbour layouts. Secondly, the radial stress components in waves were determined from the expressions

$$
\begin{gathered}
S_{x x}=\rho \frac{g}{2}\left(F_{u}+F_{p}\right), \\
S_{x y}=\rho \frac{g}{2} F_{u v},
\end{gathered}
$$

\footnotetext{
* Asterisks mark coloured figures on unnumbered inserts.
} 


$$
S_{y y}=\rho \frac{g}{2}\left(F_{v}+F_{p}\right),
$$

where $\rho$ is water density.

The values of $F_{u}, F_{u v}, F_{v}, F_{p}$ were calculated as

$$
\begin{gathered}
F_{u}=\int_{0}^{2 \pi} \cos ^{2} \theta(1+G) E(\theta) d \theta, \\
F_{u v}=\int_{0}^{2 \pi} \sin \theta \cos \theta(1+G) E(\theta) d \theta, \\
F_{v}=\int_{0}^{2 \pi} \sin ^{2} \theta(1+G) E(\theta) d \theta, \\
F_{p}=\int_{0}^{2 \pi} G E(\theta) d \theta, \quad G=\frac{2 k d}{\sinh (2 k d)},
\end{gathered}
$$

where $k$ and $d$ are constants describing wave steepness and propagation.

Calculated radial stresses were used as initial data for the circulation calculations near the harbours $\left[{ }^{9}\right]$.

\subsection{Layouts of the harbours}

Several versions of harbour layouts for each proposed harbour site were considered. The location of the main breakwater and berthing quays was established according to the wave hindcast calculations using MIKE 21 NSW for wave trains running to the site from different directions.

A refined modelling was performed with WAM $\left[{ }^{8}\right]$. In this case a grid $1 \times 1 \mathrm{mi}$ was used. Results obtained with WAM and NSW models were compared. In the regions which are located more than $1 \mathrm{~km}$ offshore, the models agree reasonably well. But for some nearshore areas the values obtained with WAM seem to be almost 3 times larger than the ones obtained with the NSW model. This feature is especially obvious in the areas which are protected by a piece of land from the wave trains arriving to the site. Evidently, WAM with minimum grid spacing of $1 \times 1 \mathrm{mi}$ is not capable of resolving the diffraction of wave trains around natural land objects with dimensions less than $1 \mathrm{mi}$. At the same time, the NSW model with grid spacing $100 \times 20 \mathrm{~m}$ seems to predict wave heights in these areas satisfactorily.

Undva harbour (Fig. 3). This site is characterized by very shallow slope of the bed and limestone covered with the layers of limestone shivers. In order to reduce the volume of the limestone to be extracted from the harbour basins and 
navigation channels, the front of the harbour is removed off the shoreline. Significant wave heights acting on the breakwater are as given in Table 1.

The turning radius of the biggest vessel (with length $210 \mathrm{~m}$ ) is about $700 \mathrm{~m}$ and to guarantee safety navigation conditions in Uudepanga Bay, the deepest basin of the harbour with depth $10 \mathrm{~m}$ is located in the middle of the harbour. According to the wave simulations, the axis of the main part of the breakwater with total length of $350 \mathrm{~m}$ is oriented under $230^{\circ}$ (the angles are measured clockwise from north direction). From the end of that part another $180 \mathrm{~m}$ long mole, oriented under $205^{\circ}$ protects the harbour from the waves generated by NW and north winds. Southern part of the harbour with depth $3.7 \mathrm{~m}$, designed for the small vessel berthing, is protected against waves and currents by a system of three moles. Undva harbour site is characterized by relatively large limestone dredging amount of $538000 \mathrm{~m}^{3}$. The co-ordinates of the harbour at the shoreline are $58^{\circ} 30^{\prime} 10^{\prime \prime} \mathrm{N}, 21^{\circ} 54^{\prime} 40^{\prime \prime} \mathrm{E}$.

Table 1. Significant wave heights $1 \mathrm{~km}$ offshore from the harbour sites, $\mathrm{m}$

\begin{tabular}{l|c|c|c|c|c}
\hline \multirow{2}{*}{ Harbour site } & \multicolumn{5}{|c}{ Wind direction } \\
\cline { 2 - 6 } & $\mathrm{W}$ & $\mathrm{NW}$ & $\mathrm{N}$ & $\mathrm{NE}$ & $\mathrm{E}$ \\
\hline Undva & $3.5-4.0$ & $3.0-4.0$ & $1.5-2.0$ & & \\
Suuriku-Kuriku & $1.0-1.5$ & $2.0-2.5$ & $5.0-5.5$ & $4.5-5.0$ & \\
Vaigu & & & $4.2-4.6$ & $4.2-4.6$ & $0.5-1.0$
\end{tabular}

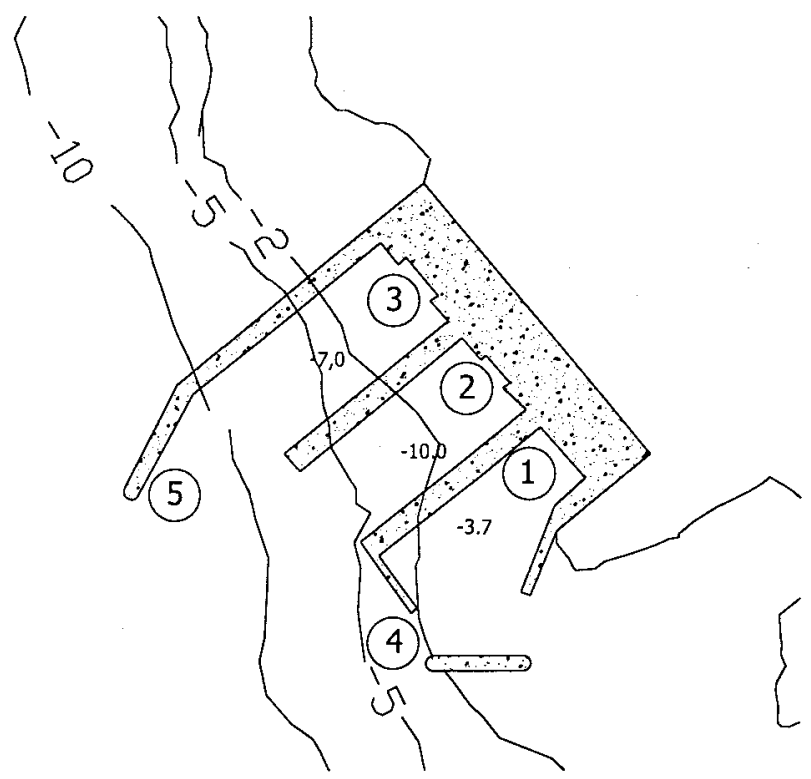

Fig. 3. Undva harbour layout with the wave calculation points. 
Suuriku-Kuriku harbour (Fig. 4). Seabed around the site is covered with limestone shivers laying on the limestone. The slope of the seabed is much steeper than at Undva and $-10 \mathrm{~m}$ isobath is located already at the distance of $400 \mathrm{~m}$ from the shoreline. Significant wave heights acting on the breakwater are given in Table 1.

Main breakwater with length of $560 \mathrm{~m}$ is first oriented under $45^{\circ}$ and another $360 \mathrm{~m}$ part is oriented under $120^{\circ}$ angle to reduce the waves running from NE. Despite of the longer breakwater than at Undva, more than a half of the breakwater is located in shallow waters with water depths less than $2 \mathrm{~m}$. It compensates the construction costs of the breakwater in the area with water depths more than $10 \mathrm{~m}$. From the other side, there is no need for dredging in the $-10 \mathrm{~m}$ basin. Also the $-7.0 \mathrm{~m}$ basin does not demand much dredging. Most of the dredging is needed in the small vessels basin and navigation channels. Total volume of the limestone to be dredged is $161000 \mathrm{~m}^{3}$. The co-ordinates of the site at the shoreline are $58^{\circ} 30^{\prime} 20^{\prime \prime} \mathrm{N}, 2^{\circ} 00^{\prime} 30^{\prime \prime} \mathrm{E}$.

Considering that both Suuriku and Kuriku cliffs should be preserved, during the following stages of the harbour design the site may be shifted until $150 \mathrm{~m}$ along the seaside without significant changes in the layout. As the cliff starts close to the seashore, only customs and border guard premises can be built on the coastline. The rest of the infrastructure is to be located on the cliff.

Vaigu harbour (Fig. 5). The site is characterized by sandy seabed and shallow water in the whole territory of the future harbour. Practically in the

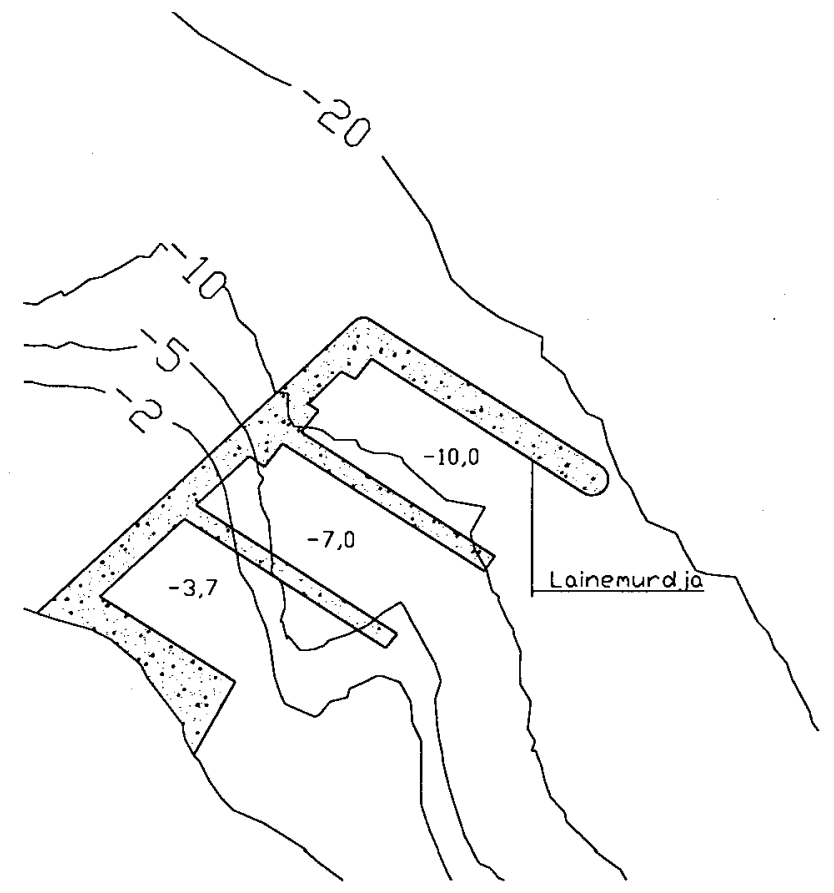

Fig. 4. Suuriku-Kuriku harbour layout with the wave calculation points. 


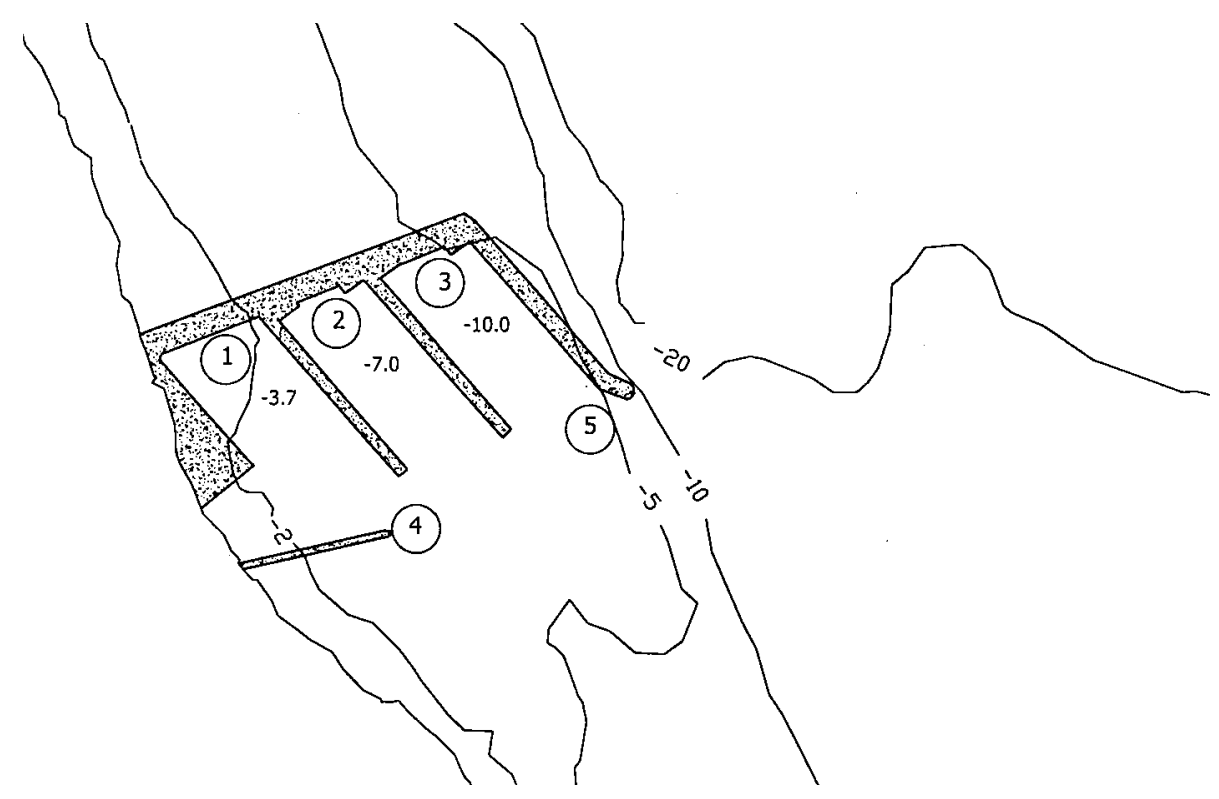

Fig. 5. Vaigu harbour layout with the wave calculation points.

whole area of berthing quays and navigation channels the sea depth does not exceed $5 \mathrm{~m}$. Wave trains running to the site are as given in Table 1 .

In this case the main breakwater should be constructed mostly under $70^{\circ}$. From the end of the breakwater a short section under $155^{\circ}$ has been designed to protect the harbour from the NE waves. Total length of the breakwater is $800 \mathrm{~m}$. Because during some periods of the year Vaigu harbour site may be influenced by the wind waves from SE, a mole which is oriented under 80 degrees in shallow waters must be constructed to protect the small vessels basin. The total volume of dredging is the biggest in comparison with other harbour sites $661000 \mathrm{~m}^{3}$. From the other side, the soil which has to be dredged is sand and the cost of extracting sand is much lower than that of limestone. Another problem at this site is that strong layers of the soil, capable to receive the loads, are situated deep under the sea bottom at about $-16 \mathrm{~m}$. This causes high cost of the harbour constructions. The co-ordinates of the harbour at the shoreline are $58^{\circ} 28^{\prime} 30^{\prime \prime} \mathrm{N}$, $22^{\circ} 02^{\prime} 30^{\prime \prime} \mathrm{E}$.

\subsection{Wave simulations in harbour basins and navigation areas of the vessels}

For evaluation of the designed layouts of the harbours, most important are the wave climate calculations with the MIKE $21 \mathrm{BW}$ model. Hydrodynamic situations at every harbour site including breakwaters, berthing quays, basins for different types of vessels, and navigation routes were examined. Wave and velocity field simulations were carried out considering the most dangerous 
directions of the wave trains running to the site from the open sea. Simulations were carried out for the following wind directions: Undva - W, NW, and N, Suuriku-Kuriku - NE, N, NW, and W, Vaigu - N, NE, and E. Wave trains running to the site were assumed to be irregular and calculated by the JONSWAP spectrum. The wave generation line is located at 1 to $1.5 \mathrm{~km}$ offshore.

Examples of these simulations for different harbour sites are shown in Figs. 6 * to $8^{*}$. These figures correspond to certain time moments during a simulated storm event. Both surface elevations and wave velocity field on the surface are presented. The wave crests (between +3.0 and $+0.5 \mathrm{~m}$ ) are green and wave troughs (between -0.5 and $-3.0 \mathrm{~m}$ ) - red. Intermediate wave heights between +0.5 and $-0.5 \mathrm{~m}$ over the " 0 " level of the Baltic Sea are shown as black isolines. Numbers added to the isolines indicate the elevation of the half amplitude of the wave. Velocity vectors are shown at every 6th point of the grid $12 \times 12 \mathrm{~m}$. The output of the model is a graph for every time step of the storm event. Every 50th time step was recorded giving the time step $2.5 \mathrm{~s}$ for the graphs. Analysing these graphs around predetermined points of each harbour layout, the wave height variations were found. These 5 points for each harbour site are indicated in Figs. 3 to 5. The comparison of the data for these points enables us to establish the poorest berthing conditions for each basin and the navigation routes of the vessels.

Maximum values of the wave amplitude when the wave trains are generated by the wind with a velocity of $25 \mathrm{~m} / \mathrm{s}$ are shown in Table 2 .

According to the simulation results, the best berthing conditions are present at Suuriku-Kuriku. Despite of the harbour location almost at the top of the peninsula, due to favourable placement of the main breakwater practically zero

Table 2. Maximum values of the wave amplitude at selected points of the harbours for various wind directions

\begin{tabular}{|c|c|c|c|c|c|}
\hline \multirow{2}{*}{$\begin{array}{c}\text { Wind } \\
\text { direction }\end{array}$} & \multicolumn{5}{|c|}{ Number of the point } \\
\hline & 1 & 2 & 3 & 4 & 5 \\
\hline \multicolumn{6}{|c|}{ Undva } \\
\hline $\mathrm{N}$ & 0.10 & 0.15 & 0.15 & 0.25 & 0.50 \\
\hline NW & 0.10 & 0.10 & 0.15 & 2.00 & 1.05 \\
\hline $\mathrm{W}$ & 0.25 & 0.60 & 0.80 & 2.00 & 1.50 \\
\hline \multicolumn{6}{|c|}{ Suuriku-Kuriku } \\
\hline $\mathrm{NE}$ & 0.20 & 0.20 & $<0.15$ & 1.05 & 1.00 \\
\hline $\mathrm{N}$ & $<0.15$ & $<0.15$ & $<0.15$ & $<0.15$ & $<0.15$ \\
\hline NW & $<0.15$ & $<0.15$ & $<0.15$ & $<0.15$ & $<0.15$ \\
\hline $\mathrm{W}$ & $<0.15$ & $<0.15$ & $<0.15$ & $<0.15$ & $<0.15$ \\
\hline \multicolumn{6}{|c|}{ Vaigu } \\
\hline $\mathrm{E}$ & 0.10 & 0.35 & 0.10 & 1.00 & 0.80 \\
\hline $\mathrm{NE}$ & 0.15 & 0.40 & 0.50 & 0.50 & 0.60 \\
\hline $\mathrm{N}$ & 0.30 & 0.35 & 0.40 & 0.30 & 0.60 \\
\hline
\end{tabular}


amplitudes of the waves are guaranteed in all the basins of the harbour by $\mathrm{W}$, $\mathrm{NW}$, and $\mathrm{N}$ winds. However, some difficulties arise when wind is blowing from NE. In the area of berthing quays in each of the harbour basins satisfactory conditions are retained, but in the entrance area to the basins the $0.8-1.0 \mathrm{~m}$ amplitude waves are predicted. On the other hand, according to the long period statistics of the wind data, the probability of the NE wave trains is only $4 \%$ and therefore difficult navigation conditions exist only during a relatively short period. First $350 \mathrm{~m}$ of the main breakwater of the harbour is located in a shallow water with the water depth less than $5 \mathrm{~m}$. Under the NW wave trains, in the area between shoreline and the outer side of the breakwater, due to the reflection, orthogonal waves are generated. This causes the area to be covered with short length sharp waves with amplitudes reaching $1.5 \mathrm{~m}$. Waves coming from the north break on the bottom cliff without reflections and the wave amplitudes in the area do not exceed $0.6 \mathrm{~m}$. Highest values of dynamic wave loads on the construction are created on the outer side of the breakwater with water depths until $14 \mathrm{~m}$ when $3.6 \mathrm{~m}$ amplitude waves coming from the north are breaking on the wall (Fig. 6).

Vaigu harbour basins are fully protected from the wave trains running from the north and NE directions. The calculations indicate also that navigation routes to different basins are well protected. Even $1.5 \mathrm{~m}$ amplitude waves are created in the area close to the harbour entrance from eastern directions despite short fetch length. According to Vilsandi Meteorological Station data, probability of eastern wind occurrence is $6 \%$ and therefore there is a number of days within a year when wave conditions make navigation of small vessels difficult. Local residents know that about $1.5 \mathrm{~m} \mathrm{SE}$ waves running alongshore may occur at the harbour site. Additional breakwater oriented to NE protects the small vessels basin well. The $4.0 \mathrm{~m}$ waves that attack the outer side of the main breakwater from the north, determine the dynamic forces to the breakwater construction. The seabed at the harbour site is characterized by fine sands with deep lying carbon layers capable to receive the loads from the construction of the berths and breakwaters. Therefore, when the local hydrodynamic balance is disturbed due to the underwater constructions of the harbour, sand transport and sediment-settling problems in the basins will arise. This indicates to the need of more detailed sediment transport research if the site is selected.

Undva harbour site which is located at the western side of the Tagamõisa Peninsula is open to the wave trains running from the sectors between west and north. There is some damping effect on the western wave amplitudes in Uudepanga Bay due to Harilaiu Bank. Because of the long main breakwater, the site is affected by the wave conditions in open sea. Proposed location of the main breakwater keeps wave conditions inside all the basins satisfactory, but at the outer side of the breakwater remarkable wave loads arise, especially during strong NW winds (Fig. 8). These winds generate up to $5.0 \mathrm{~m}$ waves which break at the breakwater. At the harbour entrance until $2.0 \mathrm{~m}$ high waves are generated with NW and west winds. In addition, up to $2.5 \mathrm{~m} / \mathrm{s}$ local current arises, making 
entrance hardly navigable for small yachts and motor boats. If Undva is selected as the harbour site, a more detailed investigation is recommended to find more suitable solution for the small vessels basin.

\section{SEDIMENT TRANSPORT CALCULATIONS}

\subsection{Description of the calculation model}

The sediment transport at the possible harbours and entry areas was calculated using software SandCalc V 2.0 developed by HR Wallingford $\left[{ }^{13}\right]$.

SandCalc is a software package created to solve the problems of sediment entrainment, transportation, and deposition in coastal areas. The package uses more than 70 different formulas and methods to find the best solution according to the corresponding local initial conditions. The results obtained are given not for the whole field of the area, but for selected points. Software package automatically controls the range of the input-output data. The whole package is divided into several parts including properties of water and materials, hydrodynamics, sediment transportation process, combined action of currents and waves, morphodynamics, scour, etc.

\subsection{Initial conditions}

The initial conditions for solving the sediment transport problems using SandCalc were obtained from the Geological Survey of Estonia $\left[{ }^{6}\right]$ and velocity fields at the harbour sites and surrounding areas were calculated using the MIKE 21 BW module.

According to the geological data, the following mean grain diameters $(d)$ have been used: Undva - shingle, $d_{50}=50 \mathrm{~mm}$; Suuriku-Kuriku - shingle, $d_{50}=50 \mathrm{~mm}$; Vaigu - in the area of the breakwater and quays fine sand layers dominate with grain diameters between 0.25 and $0.1 \mathrm{~mm}, d_{50}=0.2 \mathrm{~mm}$.

The following sea water and grain material properties have been used:

- water density $\rho=1005 \mathrm{~kg} / \mathrm{m}^{3}$

- grain density $\rho_{s}=2650 \mathrm{~kg} / \mathrm{m}^{3}$

- kinematic viscosity of water $v=1.36 \times 10^{-6} \mathrm{~m}^{2} / \mathrm{s}$

- temperature of the water $t_{w}=10^{\circ} \mathrm{C}$

- salinity of the water $7 \mathrm{ppt}$

\subsection{Conditions determining sediment transport}

The effects of the hydrodynamic forcing on the sediment dynamics due to currents and waves occur primarily through the friction of the agents exert on the seabed. This is expressed in terms of the bed shear stress $\tau_{0}$ which is the 
frictional force exerted by the flow per unit area of the bed and defined through relationship

$$
\tau_{0}=\rho u_{*}^{2},
$$

where $u_{*}$ is shear velocity.

For many purposes, a dimensionless form of the bed shear stress and its relationship to the sediment, the Shields parameter $\theta_{\mathrm{s}}$, is used, defined by

$$
\theta_{\mathrm{s}}=\frac{\tau_{0}}{g\left(\rho_{s}-\rho\right) d}
$$

The bed shear stress depends not only on the flow velocity, but also on the roughness of the seabed. This can be measured by the Nikuradze roughness $k_{\mathrm{s}}$ or by the roughness length $z_{0}=k_{\mathrm{s}} / 30$. Third factor influencing the bed shear stress is the momentum transfer to mobilize the grains.

The threshold motion of sediments on the seabed is an important factor in most of the computations of the sediment response to waves and currents. The threshold motion determines the velocity at which the grains begin to move. Calculation of the threshold is required in applications involving scour around hydraulic structures and for seabed mobility calculations. The threshold motion of sands depends on the wave generated bottom orbital velocity amplitude $U_{w}$, wave period $T$, grain diameter $d$, and density $\rho_{s}$. In case of the Saaremaa deep harbour sediment transport problems, the critical threshold wave height and corresponding orbital velocities and bed shear stresses are determined using the Komar and Miller equations $\left[{ }^{10}\right]$

$$
\begin{aligned}
& U_{\mathrm{wcr}}=[0.118 g(s-1)]^{2 / 3} d^{1 / 3} T_{\mathrm{z}}^{1 / 3}, \quad d \leq 0.5 \mathrm{~mm} \\
& U_{\mathrm{wcr}}=[1.09 g(s-1)]^{4 / 7} d^{3 / 7} T_{\mathrm{z}}^{1 / 7}, \quad d \geq 0.5 \mathrm{~mm}
\end{aligned}
$$

where $s=\rho_{s} / \rho$. Wave period in shallow water is $T_{\mathrm{z}}=11\left(H_{\mathrm{s}} / g\right)^{1 / 2}$, where $H_{\mathrm{s}}$ is significant wave height (average height of the highest third of the waves), and $T_{\mathrm{z}} \simeq T_{\mathrm{m}} \quad\left(T_{\mathrm{m}}\right.$ is the wave period).

Summary of the sediment transport calculations is presented in Tables 3 and 4. The calculations were carried out on the basis of irregular waves generated with the JONSWAP spectrum. On the basis of these data, the areas with critical wave heights have been found.

Calculations show that when $H_{\mathrm{s}}=1.0 \mathrm{~m}$, the sands at Vaigu start to migrate around the seabed even at the depth of $10 \mathrm{~m}$. The shear stresses due to the orbital velocities at the bed exceed the threshold stresses. All other significant wave heights between 1.0 and $5.5 \mathrm{~m}$ cause sand grain movement in the harbour. During the construction of breakwaters and dredging of the navigation routes the existing 
hydrodynamic balance at the site will be disturbed and considerable sediment transport will take place until a new balance will be established. Circulation and wave velocity fields, calculated with MIKE $21 \mathrm{BW}$, cause intensive sediment transport in the basins of the harbour.

Table 3. Summary of the sediment transport calculations for $d_{50}=0.2 \mathrm{~mm}$

\begin{tabular}{|c|c|c|c|c|c|c|}
\hline \multirow{2}{*}{$\begin{array}{c}H_{\mathrm{s}} \\
\mathrm{m}\end{array}$} & \multirow{2}{*}{$\begin{array}{l}\text { Sediment transport } \\
\text { parameter }\end{array}$} & \multicolumn{5}{|c|}{ Water depth, m } \\
\hline & & 4 & 6 & 8 & 10 & 12 \\
\hline \multirow[t]{4}{*}{1.0} & Bottom orbital velocity, $\mathrm{m} / \mathrm{s}$ & 0.2589 & 0.1706 & 0.1177 & 0.083 & 0.0594 \\
\hline & Bottom shear stress, $\mathrm{N} / \mathrm{m}^{2}$ & 8.534 & 4.283 & 0.2303 & 0.1131 & 0.0809 \\
\hline & Threshold wave height, $\mathrm{m}$ & 0.2582 & 0.3857 & 0.5606 & 0.834 & 1.187 \\
\hline & Threshold bed shear stress, N/m ${ }^{2}$ & 0.1745 & 0.1745 & 0.1745 & 0.1745 & 0.1745 \\
\hline \multirow[t]{4}{*}{1.5} & Bottom orbital velocity, $\mathrm{m} / \mathrm{s}$ & 0.4445 & 0.317 & 0.2384 & 0.184 & 0.1441 \\
\hline & Bottom shear stress, $\mathrm{N} / \mathrm{m}^{2}$ & 16.48 & 11.41 & 7.527 & 4.924 & 3.198 \\
\hline & Threshold wave height, $\mathrm{m}$ & 0.2404 & 0.3306 & 0.4343 & 0.5602 & 0.7179 \\
\hline & Threshold bed shear stress, N/m ${ }^{2}$ & 0.1745 & 0.1745 & 0.1745 & 0.1745 & 0.1745 \\
\hline \multirow[t]{4}{*}{2.5} & Bottom orbital velocity, $\mathrm{m} / \mathrm{s}$ & 0.828 & 0.6229 & 0.4971 & 0.4093 & 0.435 \\
\hline & Bottom shear stress, $\mathrm{N} / \mathrm{m}^{2}$ & 27.51 & 17.45 & 17.11 & 14.98 & 12.44 \\
\hline & Threshold wave height, $\mathrm{m}$ & 0.2404 & 0.3137 & 0.3872 & 0.4648 & 0.5492 \\
\hline & Threshold bed shear stress, $N / \mathrm{m}^{2}$ & 0.1745 & 0.1745 & 0.1745 & 0.1745 & 0.1745 \\
\hline \multirow[t]{4}{*}{3.0} & Bottom orbital velocity, $\mathrm{m} / \mathrm{s}$ & 1.021 & 0.7787 & 0.6299 & 0.5262 & 0.4484 \\
\hline & Bottom shear stress, $\mathrm{N} / \mathrm{m}^{2}$ & 46.79 & 21.85 & 16.85 & 17.22 & 15.99 \\
\hline & Threshold wave height, $\mathrm{m}$ & 0.2432 & 0.3133 & 0.3816 & 0.4514 & 0.5248 \\
\hline & Threshold bed shear stress, N/m ${ }^{2}$ & 0.1745 & 0.1745 & 0.1745 & 0.1745 & 0.1745 \\
\hline \multirow[t]{4}{*}{4.0} & Bottom orbital velocity, $\mathrm{m} / \mathrm{s}$ & 1.409 & 1.093 & 0.8991 & 0.7642 & 0.6628 \\
\hline & Bottom shear stress, $\mathrm{N} / \mathrm{m}^{2}$ & 106.4 & 51.54 & 29.77 & 18.96 & 15.42 \\
\hline & Threshold wave height, m & 0.249 & 0.3163 & 0.3791 & 0.4415 & 0.5041 \\
\hline & Threshold bed shear stress, N/m & 0.1745 & 0.1745 & 0.1745 & 0.1745 & 0.1745 \\
\hline \multirow[t]{4}{*}{4.5} & Bottom orbital velocity, $\mathrm{m} / \mathrm{s}$ & 1.604 & 1.251 & 1.035 & 0.8844 & 0.7715 \\
\hline & Bottom shear stress, $\mathrm{N} / \mathrm{m}^{2}$ & 14.7 & 72.67 & 42.51 & 27.39 & 18.78 \\
\hline & Threshold wave height, m & 0.2519 & 0.3186 & 0.3804 & 0.4403 & 0.50 \\
\hline & Threshold bed shear stress, $\mathrm{N} / \mathrm{m}^{2}$ & 0.1745 & 0.1745 & 0.1745 & 0.1745 & 0.1745 \\
\hline \multirow[t]{4}{*}{5.5} & Bottom orbital velocity, m/s & 1.994 & 1.567 & 1.307 & 1.127 & 0.9908 \\
\hline & Bottom shear stress, $\mathrm{N} / \mathrm{m}^{2}$ & 260.20 & 129.20 & 76.90 & 50.59 & 35.28 \\
\hline & Threshold wave height, $\mathrm{m}$ & 0.2575 & 0.3237 & 0.3839 & 0.4412 & 0.4972 \\
\hline & Threshold bed shear stress, N/m $\mathrm{m}^{2}$ & 0.1745 & 0.1745 & 0.1745 & 0.1745 & 0.1745 \\
\hline
\end{tabular}


Table 4. Summary of the sediment transport calculations for $d_{50}=50 \mathrm{~mm}$

\begin{tabular}{|c|c|c|c|c|c|c|}
\hline \multirow{2}{*}{$\begin{array}{c}H_{\mathrm{s}} \\
\mathrm{m}\end{array}$} & \multirow{2}{*}{$\begin{array}{l}\text { Sediment transport } \\
\text { parameter }\end{array}$} & \multicolumn{5}{|c|}{ Water depth, m } \\
\hline & & 4 & 6 & 8 & 10 & 12 \\
\hline \multirow[t]{4}{*}{2.0} & Bottom orbital velocity, $\mathrm{m} / \mathrm{s}$ & 0.6358 & 0.4687 & 0.3661 & 0.2946 & 0.2413 \\
\hline & Bottom shear stress, $\mathrm{N} / \mathrm{m}^{2}$ & 23.66 & 16.15 & 11.96 & 9.263 & 7.371 \\
\hline & Threshold wave height, $\mathrm{m}$ & 2.677 & 3.556 & 4.485 & 5.517 & 6.70 \\
\hline & Threshold bed shear stress, $\mathrm{N} / \mathrm{m}^{2}$ & 44.56 & 44.56 & 44.56 & 44.56 & 44.56 \\
\hline \multirow[t]{4}{*}{3.0} & Bottom orbital velocity, $\mathrm{m} / \mathrm{s}$ & 1.021 & 0.7787 & 0.6299 & 0.5262 & 0.4484 \\
\hline & Bottom shear stress, $\mathrm{N} / \mathrm{m}^{2}$ & 37.71 & 26.19 & 19.81 & 15.71 & 12.83 \\
\hline & Threshold wave height, m & 2.672 & 3.442 & 4.193 & 4.96 & 5.766 \\
\hline & Threshold bed shear stress, $\mathrm{N} / \mathrm{m}^{2}$ & 44.56 & 44.56 & 44.56 & 44.56 & 44.56 \\
\hline \multirow[t]{4}{*}{4.0} & Bottom orbital velocity, m/s & 1.409 & 1.093 & 0.8991 & 0.7642 & 0.6628 \\
\hline & Bottom shear stress, $\mathrm{N} / \mathrm{m}^{2}$ & 299.3 & 37.85 & 28.93 & 23.21 & 19.19 \\
\hline & Threshold wave height, m & 2.662 & 3.82 & 4.057 & 4.72 & 5.389 \\
\hline & Threshold bed shear stress, $\mathrm{N} / \mathrm{m}^{2}$ & 44.56 & 44.56 & 44.56 & 44.56 & 44.56 \\
\hline \multirow[t]{4}{*}{4.5} & Bottom orbital velocity, m/s & 1.604 & 1.251 & 1.035 & 0.8844 & 0.715 \\
\hline & Bottom shear stress, $\mathrm{N} / \mathrm{m}^{2}$ & 387.9 & 44.13 & 33.85 & 27.25 & 22.73 \\
\hline & Threshold wave height, $\mathrm{m}$ & 2.663 & 3.368 & 4.022 & 4.655 & 5.286 \\
\hline & Threshold bed shear stress, $N / \mathrm{m}^{2}$ & 44.56 & 44.56 & 44.56 & 44.56 & 44.56 \\
\hline \multirow[t]{4}{*}{5.5} & Bottom orbital velocity, $\mathrm{m} / \mathrm{s}$ & 1.994 & 1.567 & 1.307 & 1.127 & 1.22 \\
\hline & Bottom shear stress, $\mathrm{N} / \mathrm{m}^{2}$ & 599.5 & 370.2 & 44.29 & 35.9 & 40.16 \\
\hline & Threshold wave height, m & 2.671 & 3.357 & 3.981 & 4.575 & 5.156 \\
\hline & Threshold bed shear stress, $\mathrm{N} / \mathrm{m}^{2}$ & 44.56 & 44.56 & 44.56 & 44.56 & 44.56 \\
\hline \multirow[t]{4}{*}{6.5} & Bottom orbital velocity, $\mathrm{m} / \mathrm{s}$ & 2.384 & 1.885 & 1.581 & 1.37 & 1.212 \\
\hline & Bottom shear stress, $\mathrm{N} / \mathrm{m}^{2}$ & 875.4 & 547.3 & 358.0 & 46.16 & 38.72 \\
\hline & Threshold wave height, m & 2.682 & 3.356 & 3.963 & 4.533 & 5.083 \\
\hline & Threshold bed shear stress, $\mathrm{N} / \mathrm{m}^{2}$ & 44.56 & 44.56 & 44.56 & 44.56 & 44.56 \\
\hline
\end{tabular}

Much better is the situation at Undva and Suuriku-Kuriku with mean grain diameter $d_{50}=50 \mathrm{~mm}$. Here the limestone shingle covering the bed starts to move at $H_{\mathrm{s}}=3.0 \mathrm{~m}$ with water depth of $4 \mathrm{~m}$ and at $H_{\mathrm{s}}=4.5 \mathrm{~m}$ with $10 \mathrm{~m}$ depth of the sea. According to the wave simulations, critical situation at both sites arises at the northern side of the main breakwater where scour processes occur. Scoured material will be transported under the influence of the wave trains towards the top of the main breakwater. At Undva it may be carried with NW and west wave trains to the harbour basins when $H_{\mathrm{s}}=4.5 \mathrm{~m}$. At Suuriku-Kuriku, the influence of north and NW wave trains on the scoured material carries it to the deep water area $\left(H_{\mathrm{s}} \geq 12 \mathrm{~m}\right)$. Here the waves influence little the grains laying on the bed and the scoured material settles. Circulation currents and orbital wave velocities at the bed, generated by the wave trains from NE and east, are negligible and do not cause re-sedimentation problems in the harbour basin. 


\section{DISCUSSION}

The construction of hydrotechnical structures connected with harbours is very expensive. Therefore detailed analysis of the future harbour locations is important. Mistakes in that phase of development can result in various difficulties in harbour construction and operation. The amount of money spent on the correction of these mistakes is usually for many orders of magnitude bigger than the money spent for the design. In the present case the best harbour site should be selected considering the harbour layout design, safe berthing conditions by different weather conditions, safe navigation routes, subsoil characteristics under the breakwaters and berthing constructions, sediment transport problems, location of the harbour infrastructures, etc.

The results of this study suggest that Suuriku-Kuriku harbour site should be selected on the following reasons:

- best wave climate of the harbour basins and navigation routes,

- solid basement layers under the breakwaters and berthing quays,

- small risk of the sediment transport in the basins of the harbour,

- minimum volume of the limestone dredging,

- almost half of the total length of the main breakwater is located in shallow water $(h \leq 5 \mathrm{~m})$ causing low costs of the construction.

A negative moment of this harbour site is the following. A part of the main breakwater, protecting the harbour basins against NE waves, is to be constructed in relatively deep waters on the limestone layer laying at the depth of more than $12 \mathrm{~m}$. At the same time, when the breakwater is finished, the $-10 \mathrm{~m}$ basin is ready for the vessels berthing without additional dredging.

Despite the fact that the wave climate at Vaigu is almost the same as at Suuriku-Kuriku, sandy bed at Vaigu causes sediment transport into the harbour basins and filling of the dredged navigation routes. Volume of the proposed dredging work is the greatest, but dredging of the sandy bed is cheaper than that of limestone at the other sites. The maintenance costs are large due to the expected backfill of the navigation routes. Limestone layers receiving the loads from the constructions are laying relatively deep ( $16 \mathrm{~m}$ under the sea level).

Undva harbour site is open to the wave trains running from west and NW directions and therefore the total length of breakwaters to be constructed is greatest. Location of the harbour site is determined by the winds and turning radiuses of the greatest vessels. The wave climate in the entrance area of the small vessels basin by west winds is not satisfactory. Very important negative moment is the big amount of limestone dredging works (more than $0.5 \times 10^{6} \mathrm{~m}^{3}$ ) to ensure the demanded depths of the harbour basins and navigation routes.

All the investigations presented in this issue give a lot of information for selecting the best site for the Saaremaa deep harbour. However, during the next steps of the project economic analysis of the possible solutions should be included. 


\section{ACKNOWLEDGEMENTS}

This study has been performed in the framework of hydrodynamical and geological investigations of the possible locations of the Saaremaa deep harbour, financed by the Estonian Centre of Environment Studies, Ministry of Environment.

\section{REFERENCES}

1. Maritime Works Recommendations: Geotechnical Recommendations for the Design of Maritime and Harbour Works. Puertos del Estado, Madrid, 1995. CD-ROM 0.5-94.

2. Maritime Works Recommendations: Actions in the Design of Maritime and Harbour Works. Puertos del Estado, Madrid, 1990. CD-ROM 0.5-94.

3. Recommendations of the Committee for Waterfront Structures, Harbours and Waterways, 6th English Edition. Erns und Sohn Verlag für Architektur und technische Wissenschaften, Berlin, 1992.

4. Technical Design Recommendations for Sea Ports VMTP-01-78. Morflot, Moscow, 1978 (in Russian).

5. Design Recommendations for Sea Ports RD31.31.47-88. Morflot, Moscow, 1988 (in Russian).

6. Kask, J., Perens, H., Perens, R., Suuroja, S., and Kask, A. Comparison of geological settings at possible deep harbour sites, north-western Saaremaa Island. Proc. Estonian Acad. Sci. Eng., 2001, 7, 99-125.

7. Kõuts, T. and Laanearu, J. Variability of currents in bays of Tagalaht and Uudepanga. Proc. Estonian Acad. Sci. Eng., 2001, 7, 126-140.

8. Soomere, T. Wave regimes and anomalies off north-western Saaremaa Island. Proc. Estonian Acad. Sci. Eng., 2001, 7, 157-173.

9. Elken, J. Modelling of coastal circulation and oil drift at possible deep harbour sites, northwestern Saaremaa Island. Proc. Estonian Acad. Sci. Eng., 2001, 7, 141-156.

10. MIKE 21, Nearshore Spectral Wind-Wave Module. Release 2.5, User Guide and Reference Manual. Danish Hydraulic Institute, Horsholm, Denmark.

11. MIKE 21, Boussinesq Wave Module. Release 2.5, User Guide and Reference Manual. Danish Hydraulic Institute, Horsholm, Denmark.

12. Sinusoidal and Cnoidal Gravity Waves Formulae and Tables. TU Denmark, Lyngby, 1978.

13. Soulsby, R. Dynamics of Marine Sands. Thomas Telford Publ., London, 1997.

\section{SAAREMAA SÜVASADAMA PÕHIPLAANI KAVANDAMINE NING LAINETUSE JA SETTEAINETE TRANSPORDI MATEMAATILINE MODELLEERIMINE}

\section{Toomas LIIV ja Uno LIIV}

On kavandatud Saaremaa süvasadama põhiplaan kolme võimaliku sadamakoha jaoks. Nende väljatöötamisel on lähtutud geoloogilistest ja hüdrometeoroloogilistest tingimustest ning avamerel tekkivate tuulelainete ja lahtedes tekkivate hoovuste, reostuse leviku ja piirkonnale sadamate rajamisega kaasneva mõju uuringutest. Vastavalt väljatöötatud põhiplaanidele on matemaatiliselt modelleeritud lainetuse ja kiiruste väljad sadamakohtade ümbruses, lainemurdjate lähe- 
duses ja sadamate erineva sügavusega basseinides kasutades rannalähedaste protsesside modelleerimise matemaatilist mudelit MIKE 21. Lainetuse karakteristikud on määratud iga sadama asukoha seisukohalt olulistest ilmakaartest kiirusega $25 \mathrm{~m} / \mathrm{s}$ puhuvate tuulte genereeritud lainete põhjal. Kasutades SandCalc 2.0 mudelit ja arvestades mere põhjas esineva materjali omadusi on analüüsitud lainetusest tekkivaid nihkepingeid ning nendest tingitud uhtumist ja settimist. Selgub, et kolmest võimalikust sadamakohast on otstarbekaim Suuriku-Kuriku. Selle sadama kavandatud konstruktsioon kaitseb prevaleerivate tuulte korral akvatooriumi hästi. Uhtainete liikumine sadama akvatooriumisse ei ole merepõhja iseloomu tõttu probleem. Samuti on selles sadamakohas vajalikud süvendustööd väiksemamahulised kui teistes. 